Canan Eryigit,

Ph.D., Associate Professor, Hacettepe University, Turkey

ORCID ID, 0000-0002-4326-3922

email: canand@hacettepe.edu.tr

Correspondence author: canand@hacettepe.edu.tr

\title{
CONSUMER INNOVATIVENESS: A LITERATURE REVIEW
}

Abstract. This paper reports the results of a systematic review of recent literature on consumer innovativeness. The main purpose of the research is to identify the current research themes, understand emerging themes, and predict future directions in consumer innovativeness research. Previous reviews were either narrowly scoped or needed to be updated. Accordingly, the current literature review may fill this gap in the literature. The study sample is 188 articles published in journals indexed in the Web of Science database in the last decade. Content analysis was employed by using quantitative and narrative approaches. Based on the content analysis, these articles were assigned to five research themes as follows: 1) consequences of consumer innovativeness; 2) antecedents of consumer innovativeness; 3) the moderating role of consumer innovativeness; 4) the mediating role of consumer innovativeness; 5) measurement of consumer innovativeness. The findings showed that the highest proportion of articles reviewed in this study involve research that examines the consequences of consumer innovativeness. New product adoption is the most commonly identified consequence of consumer innovativeness. The next most common research themes were the moderator role and antecedents of consumer innovativeness. Articles in the measurement of consumer innovativeness were relatively rare. The fewer number of articles in the research theme indicates that measurement of consumer innovativeness has been well identified in the previous studies. The mediator role of consumer innovativeness was not common in the last decade. The research themes were examined in detail by providing the variables included in the previous studies and the study findings, as well. The research confirms the crucial role of consumer innovativeness in adoption. Besides, the findings indicated the augmented role of consumer innovativeness in consumer behaviour literature. The results of the research can be useful for guiding future research.

Keywords: antecedents of consumer innovativeness, consumer innovativeness, content analysis systematic literature review, consequences of consumer innovativeness.

Introduction. New product failure rates are high in many industries (Fu and Elliott, 2013). The success of a new product depends mostly on customer acceptance and customer satisfaction (Huang et al., 2004). Accordingly, innovative consumers constitute a vital market segment, and identification of innovators and understanding factors predicting innovativeness are accepted as valuable. Regarding this, research examining consumer innovativeness has become extensive (Kim et al., 2017). Previous studies focused on conceptualization and measurement of consumer innovativeness (Kaushik et al., 2014; Lee and Mano, 2014; Roehrich, 2004). Moreover, the previous studies aimed at determining factors which affect consumer innovativeness (Bartels and Reinders, 2011; Lassar et al., 2005) and influence of innovativeness on purchase intention (Clark and Goldsmith, 2006; Hwang et al., 2019). The broad and comprehensive literature on consumer innovativeness $(\mathrm{Cl})$ leads to studies aimed at reviewing previous studies. However, those review studies (Bartels and Reinders, 2011; van Oorschot et al., 2018; Roehrich, 2004) lack updated, systematic or comprehensive syntheses of research findings. From these points, this study aims to identify the current research themes, understand emerging themes, and predict future directions in consumer innovativeness research. For that purpose, a systematic review of recent literature on consumer innovativeness was conducted. The paper is organized as follows. First, the concept of innovativeness is described, and previous studies reviewing the literature on consumer innovativeness

Cite as: Eryigit, C. (2020). Consumer Innovativeness: a Literature Review. Marketing and Management of Innovations, 3, 106-119. http://doi.org/10.21272/mmi.2020.3-08 
are summarized. Next, the methodology of the current review is provided. Afterwards, the results of the review are presented. Current trends and possible directions for future research are outlined in conclusion.

Literature Review. Innovativeness is «the degree to which an individual is relatively earlier in adopting new ideas than other members of a system» (Rogers, 1983). More simply, innovativeness is the relative early purchase of new products (Midgley and Dowling, 1978). However, this definition only covers the behavioural aspect of being innovative. Innovativeness can also be regarded as a personality trait and defined as «the degree to which an individual is receptive to new ideas and makes innovation decisions independently of the communicative experience of others» (Midgley and Dowling, 1978). The former is referred to as actualized innovativeness and includes the act of adoption or innovative behaviour. The latter is referred to as innate innovativeness or global personality trait and covers the willingness to try new things (Goldsmith and Foxall, 2003; Midgley and Dowling, 1978). Another view supposed that consumers can be more innovative in a product category whereas less innovative in another product category. Accordingly, the concept of domain-specific innovativeness has been offered and defined as «the tendency to learn about and adopt new products in a specific domain of interest» (Goldsmith and Hofacker, 1991). Consequently, there are three different levels of consumer innovativeness as follows: innovative behavior, innate innovativeness, and domain-specific innovativeness. Consumer innovativeness is the direct predictor of new product adoption (Slade et al., 2015; Wang et al., 2008). For instance, the study (Nikou, 2019) conducted in Finland showed that $\mathrm{Cl}$ significantly positively influences the intention to use smart home technologies. Similarly, consumer preference for electric vehicles is influenced by $\mathrm{Cl}$ (Morton et al., 2016). Another study (Handarkho and Harjoseputro, 2019) conducted on mobile payments indicated a significant effect of $\mathrm{Cl}$ on the intention to adopt. Accordingly, it is essential to determine the level of innovativeness and its antecedents. There is a stream of research focusing on conceptualization and measurement of innovativeness, as well as factors affecting innovativeness (Bartels and Reinders, 2010; Goldsmith and Foxall, 2003; Kaushik et al., 2014; Konuk, 2019; Lee and Mano, 2014; Roehrich, 2004). The extensive and comprehensive literature on consumer innovativeness leads to studies aimed at reviewing the previous studies. Roehrich (2004) aimed to examine different conceptualizations and attempts to measure consumer innovativeness. Bartels and Reinders (2011) reviewed 79 studies on the ISI index and identified the use of three levels of innovativeness. They offered a theoretical model, including factors affecting three levels of innovativeness, relationships across three levels, and factors moderating these relationships. The proposed model is comprehensive; however, it needs to be updated, including recent studies. With a similar approach, Kaushik et al. (2014) reviewed 101 articles on consumer innovativeness, published from 1971 to 2013. They offered an updated model of Bartels \& Reinders's (2011) study. Another study (Kim et al., 2017) reviewed the articles that have cited Kim et al.'s (2012) paper covering the period of 2013- 2017. This review had a narrow focus as it has only covered documents citing a specific article. Van Oorschot et al. (2018) made a bibliographic review of innovation adoption covering 2013-2016. The study was not explicitly related to consumer innovativeness but include more topics such as organizational innovativeness and diffusion process.

Methodology and research methods. Based on the existing literature reviews provided above, it can be concluded that there is a need for an updated and systematic review of consumer innovativeness research. In turn, directions for future research can be provided. In the frame of this study, a systematic literature review was conducted to synthesize previous studies. The systematic review process prevents reviewer bias through an objective selection of articles (Denyer and Tranfield, 2006; Hammersley, 2001). The review process can be described as follows. At first, the scope of the systematic literature review was identified. For this purpose, the database and the time period were identified. The review covered the journals indexed in the Web of Science (WOS) Core Collection database. The WOS database was selected as it is accepted as the world's premier scientific citation search platform, including leading scholarly journals and large-scale data-intensive studies (Li et al., 2018). The scope of the systematic literature review was restricted to journal articles published in the last decade. Thus, the period covers the 
years 2010-2020 (until April). In the second step, the keywords were determined. The keywords were used as follows: "consumer innovativeness», «domain-specific innovativeness», «innovativeness and consumer» and «innate innovativeness». This search resulted in nearly 700 articles. In the third step, the sample of articles was identified based on the article selection criteria. The article's focus on "consumer» was the main criterion for articles selection. Accordingly, the title, abstract, and keywords of the articles were further examined. This examination indicated that some of those articles are related to organizational or product innovativeness. Thus, they were eliminated from the sample. Duplications were also removed. Besides, only empirical research studies and English written articles were selected. Accordingly, a total of 188 articles met the criteria and formed the research subjects of the present study. Lastly, the articles were analyzed according to the sources, years of publication, research themes, and topics based on content analysis.

Results. The article selection process resulted in 188 articles for review. The articles were published in 115 different journals. Figure 1 shows the sources of these articles. The Journal of Business Research accounted for most of the articles relating to consumer innovativeness (4.74\% of articles). The Technological Forecasting and Social Change accounted for $3.7 \%$, and The Journal of Product Innovation Management for $3.168 \%$ of articles. Telematics and Informatics, British Food Journal, Computers in Human Behavior, European Journal of Marketing, International Journal of Research In Marketing, Journal of Consumer Marketing, Journal of Travel Research, Psychology \& Marketing accounted for $2.11 \%$ of the articles. Other journals less frequently published articles relating to consumer innovativeness. Accordingly, consumer innovativeness is under the scope of various journals, depending on the new product examined in the paper. For example, studies (Chu et al., 2019; Morton et al., 2016) examining the effect of $\mathrm{Cl}$ on the adoption of electric vehicles published in transportation scoped journals such as Research In Transportation Business And Management, Transportation Research Part D-Transport and Environment. Studies (Morosan and DeFranco, 2016, 2019; de Oliveira Santini et al., 2018; Wang, 2014) conducted on tourism products or tourist innovativeness published in hospitality-related journals; e.g., International Journal of Contemporary Hospitality Management, International Journal of Tourism Research, Journal of Travel Research.

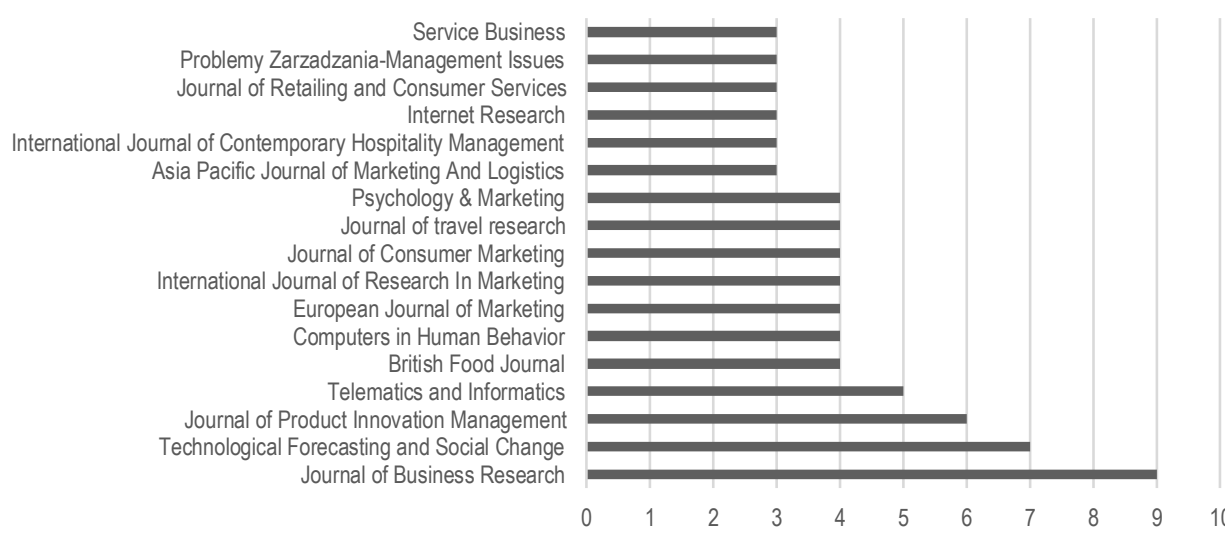

Figure 1. The Sources of Articles (only those having three or more articles are presented) Sources: developed by the authors.

Although the scope of journals is broad. In turn, most of the articles were related to the «business» and «management» categories ( $n=91, n=39$, respectively). These categories are followed by «hospitality leisure sport tourism» $(n=21)$. There are also studies under the category of «computer science information 
systems» and «information science library science» $(n=12)$. The relatively fewer number of studies are under the category of «engineering industrial» $(n=8)$, «regional urban planning» $(n=8)$, «food science technology» $(n=6)$, and «agricultural economics policy» $(n=5)$. These findings show the interdisciplinary nature of the consumer innovativeness concept. Figure 2 shows the yearly distribution of articles. Although the number of articles has been increasing, there is no stable trend. For instance, the number of articles decreased sharply in 2017 than started to grow. In 2016, the number of articles was maximum, indicating a peak in the covered period.

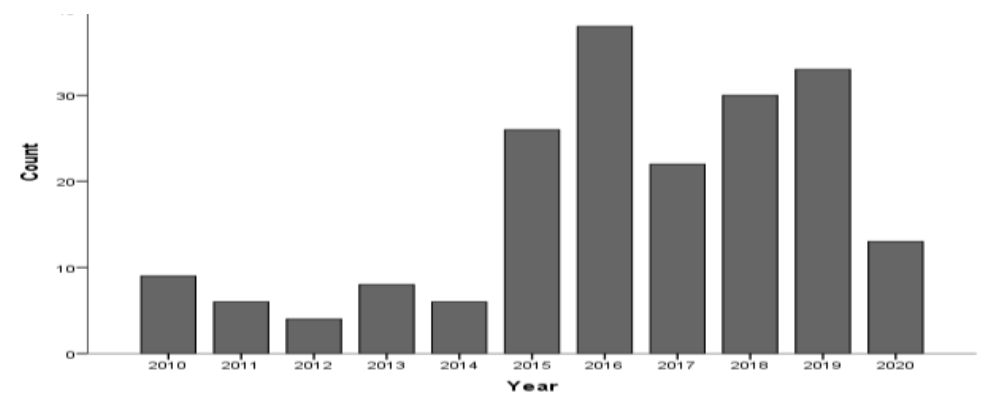

Figure 2. The Yearly Distribution of Articles

Sources: developed by the authors.

The Results of the Content Analysis. One hundred eighty-eight selected articles were assigned to one of the five research themes, namely consequences, moderator role, mediator role, antecedents, and measurement. The research themes were determined by the author based on a content analysis of each paper. Accordingly, content analysis was performed with a manual process of reading and coding the articles. The author analyzed the purpose of the study, the variables, and the models or hypotheses and coded the articles into research themes. The descriptive statistics were made with the use of Microsoft Excel 2019 and SPSS 23 programs. Consequently, both quantitative and narrative approaches were employed (Popay et al., 2006). A randomly drawn subset of 38 articles (20\% of the sample) was verified by a researcher different from the original coder (Davis et al., 2011). The independent coder's review was consistent, with $95 \%$ of our coding. This value shows high classification reliability. The content analysis indicates that the highest proportion of reviewed articles $(70.10 \%)$ reports the results of research on the consequences of consumer innovativeness (see Table 1). The next most widely examined research theme was the moderator role of $\mathrm{Cl}(12.37 \%)$. It is followed by studies utilizing antecedents of $\mathrm{Cl}(9.28 \%)$. According to the content analysis, studies devoted to measurement and the mediating role of $\mathrm{Cl}$ were relatively rare $(5,15 \%$, and $3.09 \%$, respectively).

Table 1. Research Themes Based on Content Analysis

\begin{tabular}{|l|c|c|}
\hline Research Theme & $\mathbf{n}$ & $\%$ \\
\hline Consequence & 136 & 70,10 \\
\hline Moderator role & 24 & 12,37 \\
\hline Antecedents & 18 & 9,28 \\
\hline Measurement & 10 & 5,15 \\
\hline Mediator role & 6 & 3,09 \\
\hline Total & 194 & 100,00 \\
\hline
\end{tabular}

Sources: developed by the authors.

Figure 3 shows how the research themes change through time. Accordingly, the dominant research theme each year is the consequence of consumer innovativeness since the percentage of the theme is 
the highest each year. The moderating role of consumer innovativeness has been an emerging topic since 2015. The research themes of measurement and the mediating role of $\mathrm{Cl}$ were not the main focus of the literature in the last decade.

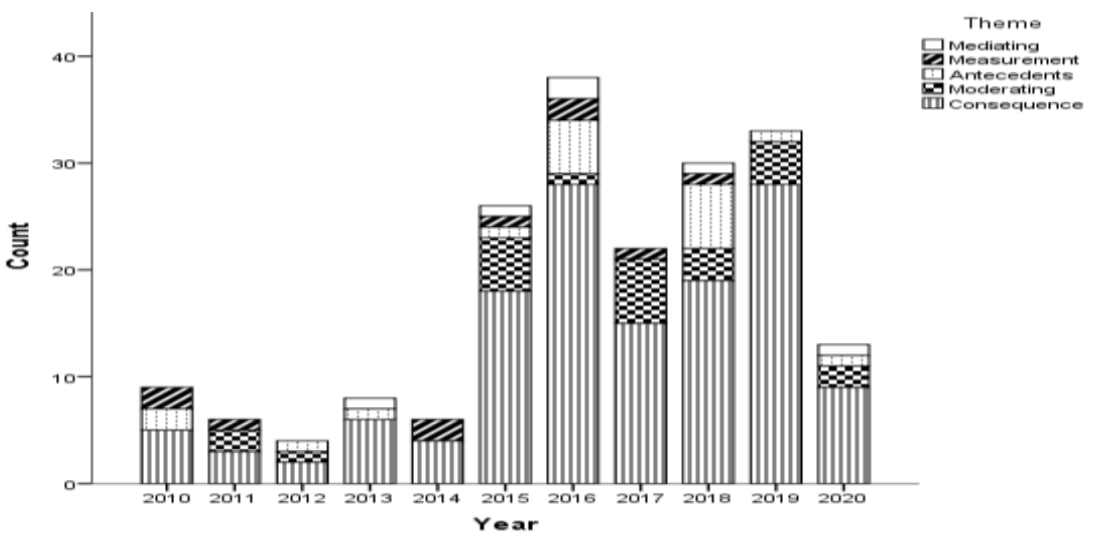

Figure 3. Distribution of Research Themes

Sources: developed by the authors.

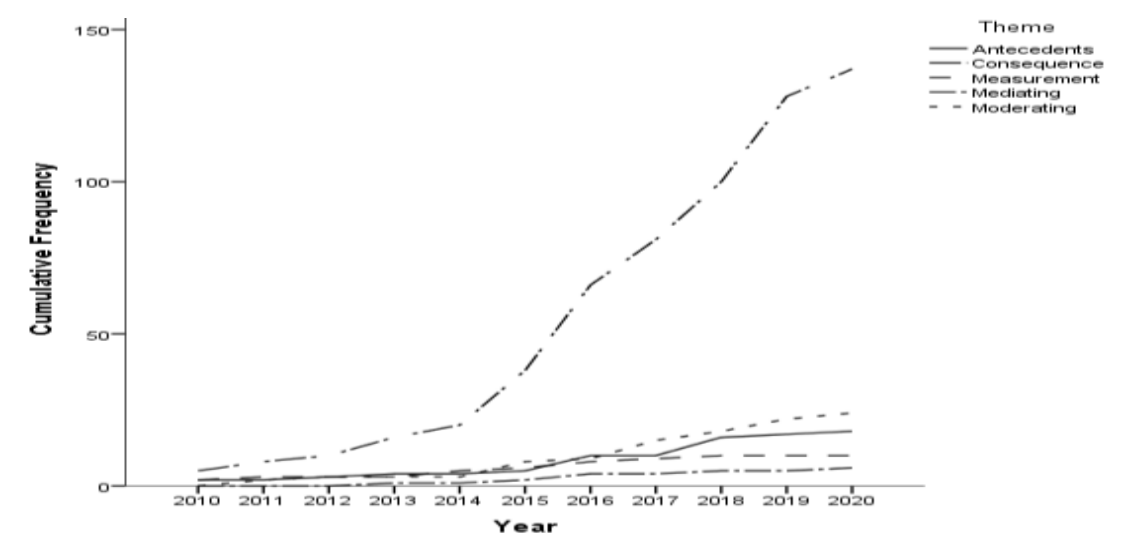

Figure 4. Cumulative Distribution of Research Themes

Sources: developed by the authors.

Figure 4 represents the cumulative number of studies in each research time for the last decade. As can be seen from Figure 4, studies examining the consequences of consumer innovativeness has been increasing at an increasing rate. This rapid growth shows the popularity of the topic. The moderating role of $\mathrm{Cl}$ has been an emerging research theme as the number of studies has been increasing, especially for the last five years. Similarly, the cumulative number of articles classified as antecedents has been growing in the previous decade. The cumulative number of articles devoted to measurement has been steady, indicating that the research theme has reached a saturation period. The same trend is also valid for the research theme «mediating role».

The results of the content analysis are discussed in detail for each research theme. Consequences of Consumer Innovativeness. The research theme covers the studies that aimed to determine the variables affected by consumer innovativeness. The results of our review indicate that various dependent variables 
were examined, such as adoption, purchase intention, repurchase intention, brand switching, brand loyalty, evaluation of product attributes, perceived value, perceived risk, willingness to pay, brand extension. Figure 5 shows the consequences of consumer innovativeness examined in the sample of articles. Only the consequences that count more than three were shown. Accordingly, the most widely examined consequence is adoption intention or adoption behaviour $(n=87,63 \%)$. It is followed by brand responses and product evaluations ( $n=17,12 \% ; n=14,10 \%$ respectively). Other less frequently mentioned consequences were perceived value $(n=9,7 \%)$, perceived convenience $(n=6,4 \%)$, and willingness to pay more $(n=5,4 \%)$.

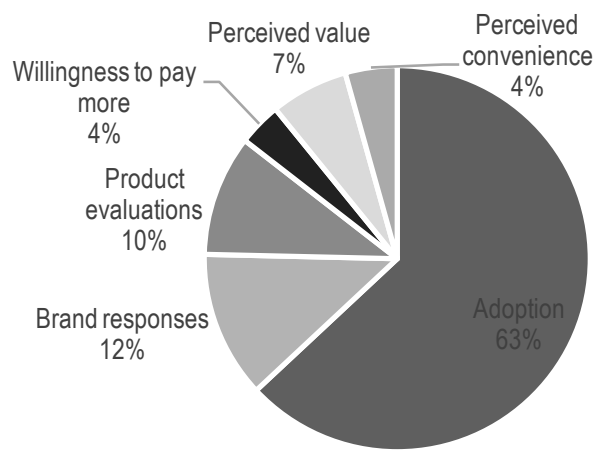

Figure 5. Consequences of Consumer Innovativeness

Sources: developed by the authors.

The new product adoption was the most widely identified consequence of consumer innovativeness. The studies cover various new products, from services to high-tech products. For instance, there is a stream of research investigated the influence of consumer innovativeness on the adoption of sustainable products and services, such as eco-innovations or green products (Biswas and Roy, 2015; Heidenreich et al., 2017; Paparoidamis and Tran, 2019; Park and Lee, 2016), electric vehicles (Chu et al., 2019; Morton et al., 2016), organic foods (Bartels and Reinders, 2010; Chakrabarti, 2010; Konuk, 2018), and sharing economy (Hwang and Griffiths, 2017; Liu and Wayne Xu, 2019; Maalouf et al., 2020). Another group of studies (Abbas et al., 2019; Chauhan et al., 2019; Cheng and Chen, 2016; Handarkho and Harjoseputro, 2019; Mahdzan et al., 2017; Shaikh et al., 2020) examined the adoption of financial products and services, e.g., online banking, crowdfunding; Islamic banking, mobile payment, and smart cards. There are also studies (Aldahdouh et al., 2020; Ashraf et al., 2019; Cheung et al., 2019; Murata et al., 2019; Ratten, 2015) focusing on the adoption of high-tech products and information technology such as wearable devices, smart home technology; social media, cyborgs, and cloud computing. Earlier studies focused on smartphones or cell phones (Lee et al., 2013; Li, 2013).

The second most widely examined consequence of consumer innovativeness is consumers' attitudinal and behavioral responses to brands. Brand responses cover response to brand extension, satisfaction, brand loyalty, brand engagement, repurchase intention and brand switching (Chang et al., 2019; Cui et al., 2018; Eren-Erdogmus et al., 2018; Kelley and Alden, 2016; Quoquab et al., 2018; San-Martin and Lopez-Catalan, 2013; Simmons et al., 2017). Another consequence of consumer innovativeness examined in the literature is consumers' product evaluations. This research theme covers studies examining attitudes toward product and consumers' perceptions about product attributes or characteristics (Kim et al., 2015; Lee, Lee, et al., 2013; Rohm et al., 2012). 
Relatively fewer studies (Al-Jundi et al., 2019; Handarkho and Harjoseputro, 2019; Konuk, 2018) investigated other consequences such as convenience, willingness to pay, and perceived value. The positive effect of $\mathrm{Cl}$ on willingness to pay more has been validated in previous studies (Konuk, 2018; Park and Lee, 2016). Relatively fewer studies investigated the impact of $\mathrm{Cl}$ on perceived value in terms of hedonic value, utilitarian value, emotional value, or perceived overall value (Al-Jundi et al., 2019; Chen and Fiore, 2017; Kim and Kim, 2017). For instance, (Hong et al., 2017) showed a positive effect of $\mathrm{Cl}$ on hedonic and utilitarian values. The Moderating and Mediating Role of Consumer Innovativeness. The studies on the moderating role of consumer Innovativeness have examined the effects of $\mathrm{Cl}$ on various relationships. Table 2 shows those studies and examined relationships. Consumers' evaluations of products were the commonly examined independent variable such as the level of product innovativeness, perceived quality, perceived value, and perceived design. The variables as repurchase intention, adoption, brand equity, and satisfaction were examined as dependent ones. Those studies mostly provided empirical evidence for the moderating role. The mediating role of consumer innovativeness has been examined in a fewer number of studies; thus, it is not possible to make conclusions on its mediating role.

Table 2. Studies Examining the Moderating Role of Consumer Innovativeness

\begin{tabular}{|l|l|}
\hline \multicolumn{1}{|c|}{ Study } & \multicolumn{1}{|c|}{ Relationship } \\
\hline Byun and Sternquist (2011) & perceived perishability, scarcity, and low price $\square$ in-store hoarding \\
\hline Hur et al. (2012) & Consumption values $\square$ purchase intention \\
\hline Jung et al. (2015) & Quality $\square$ satisfaction \\
\hline Kuester et al. (2015) & Launch price $\square$ Perceived price fairness \\
\hline Li et al. (2015) & product originality $\square$ adoption intention \\
\hline Lin et al. (2015) & Motivation \& uncertainty $\square$ E-payment use \\
\hline Nørskov et al. (2015) & Product attributes $\square$ brand equity \\
\hline Schweitzer and Van den Hende (2016) & Product design $\square$ adoption intention \\
\hline Shi et al. (2016) & Perceived relationship investment $\square$ relationship strength \\
\hline Park and Gunn (2016) & Perceived image of the product $\square$ perceived product aesthetics \\
\hline Hwang and Griffiths (2017) & Attitude \& empathy $\square$ purchase intention \\
\hline Lee and Johnson (2017) & Product design $\square$ willingness to buy \\
\hline Menidjel et al. (2017) & Brand trust $\square$ brand loyalty \\
\hline Schillo et al. (2017) & $\begin{array}{l}\text { Social identity \& social influence } \square \text { perceived value } \square \text { purchase } \\
\text { intention }\end{array}$ \\
\hline Wang et al. (2017) & Quality $\square$ satisfaction $\square$ behavioural intentions \\
\hline Zhang and Hou (2017) & Perceived risk $\square$ information search \\
\hline de Oliveira Santini et al. (2018) & Perceived value $\square$ revisit intention \\
\hline Lee and Shin (2018) & Perceived product smartness $\square$ customer satisfaction \\
\hline Gumel (2018) & Attitude \& social norm $\square$ adoption intention \\
\hline Krey et al. (2019) & Perceived value $\square$ attitude toward using the product \\
\hline Pantano et al. (2019) & Attitude toward storefront $\square$ attitude toward retailer \& entry decision \\
\hline Wang et al. (2019) & Perceived product innovativeness $\square$ brand image \& perceived value \\
\hline Abbas and Mir (2020) & $\begin{array}{l}\text { Innovation characteristics \& consumers' characteristics } \\
\text { consumers' resistance towards innovation }\end{array}$ \\
\hline Adapa et al. (2020) & Perceived smart retail technology $\square$ Perceived shopping value \\
\hline Sources: developed by the author. & \\
\hline
\end{tabular}

The Antecedents of Consumer Innovativeness. Various factors have been encountered as antecedents of consumer innovativeness in previous studies (see Table 3). These factors can be grouped into four main categories, namely, personal factors, psychological factors, social factors, and marketing mix elements. Personal factors cover family life cycle, gender, income, self - esteem, and personality traits. 
For instance, (Thakur and Jasrai, 2018) investigated the discriminating effects of the family life cycle, gender, income, and age on the level of innovativeness. The research findings showed that gender, age, and family life cycle are significant predictors of innovativeness towards mobile telecom services. Psychological factors include shopping motivations, personal values, and thinking styles. For instance, joyful consumption, altruistic, and biospheric values affect consumers' eco-innovativeness (Gurtner and Soyez, 2016). Social factors include interpersonal influence (Müller et al., 2018).

Table 3. The Antecedent Variables Examined in Previous Studies

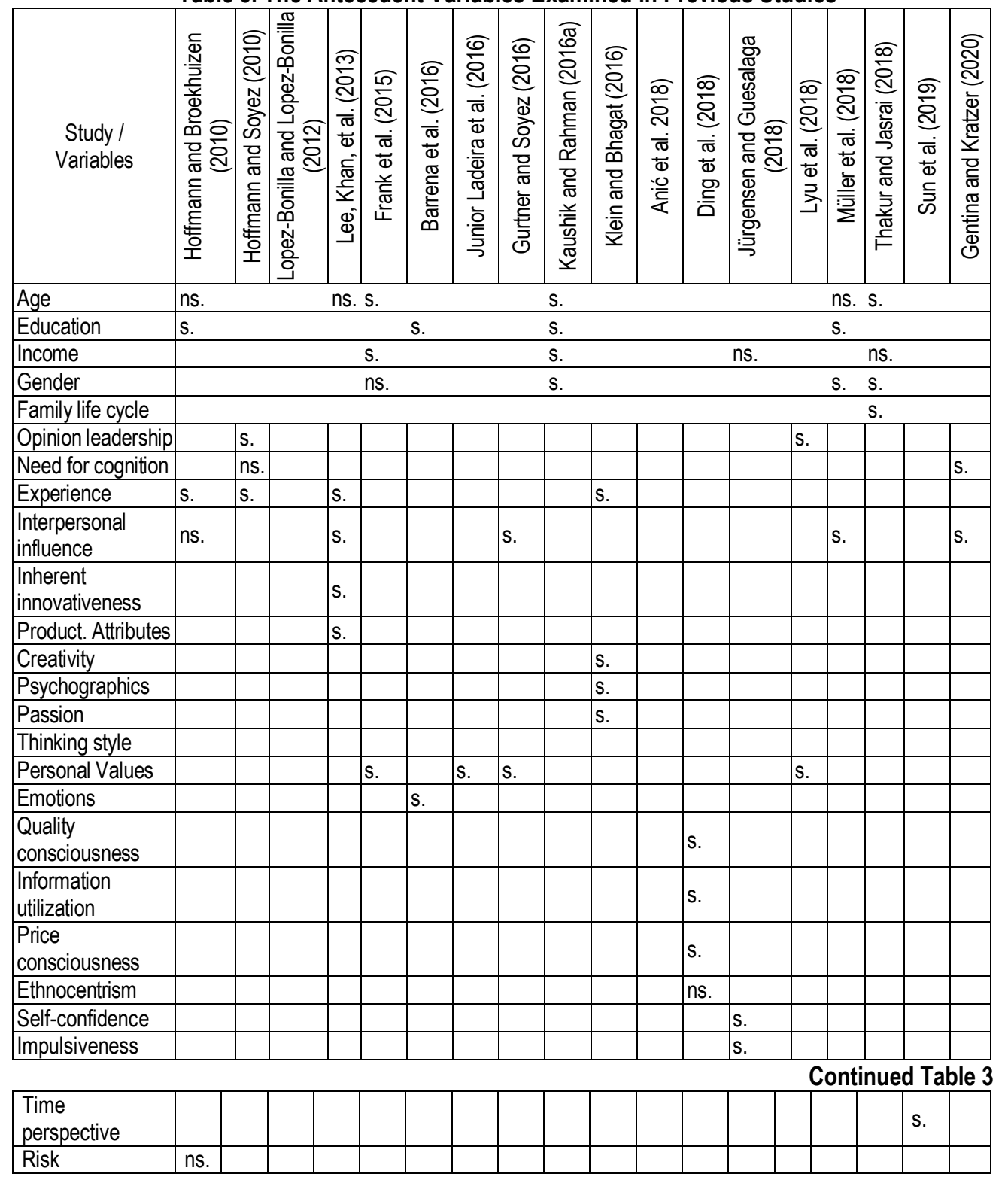




\begin{tabular}{|l|l|l|l|l|l|l|l|l|l|l|l|l|l|l|l|l|l|l|}
\hline $\begin{array}{l}\text { Market } \\
\text { mavenism }\end{array}$ & s. & & & & & & & & & & & & & & & & \\
\hline Involvement & s. & & & & & & & & & & & & & & & & \\
\hline $\begin{array}{l}\text { Ambiguity } \\
\text { tolerance }\end{array}$ & s. & & & & & & & & & & & & & & & & & \\
\hline $\begin{array}{l}\text { Shopping } \\
\text { motivations }\end{array}$ & & & s. & & & & & s. & & & s. & & s. & & & & & \\
\hline
\end{tabular}

Sources: developed by the author.

Measurement of Consumer Innovativeness. Studies focusing on measurement either validated existing scales or generates new scales. For instance, (Chao et al., 2016) tested cross-cultural validation of the vicarious innovativeness scale. (Caricati and Raimondi, 2015) validated motivated Consumer Innovativeness scale for an Italian sample. On the other hand, (Waheed et al., 2017) aimed to generate measurement for actual innovative behaviour. Similarly, (Kaushik and Rahman, 2016) developed a selfservice innovativeness scale.

Conclusion. This study reviewed the articles on consumer innovativeness published in Web of Science (WOS) indexed journals for the last decade. Content analysis was conducted to identify the current research themes, understand emerging themes, and offer future directions. The article selection process leads to 188 articles published in 115 different journals. Five research themes were identified, namely, consequence, antecedents, measurement, the moderator role, and the mediator role. The study revealed that consequences are the most studied research theme in the consumer innovativeness area over the last decade. The most widely studied consequence was the adoption of new products. The findings have indicated a positive and significant effect of $\mathrm{Cl}$ on adoption. This is consistent with the knowledge that $\mathrm{Cl}$ is crucial in explaining the characteristics of adopters (Kim et al., 2017). It can be concluded that studies focused on the effect of $\mathrm{Cl}$ on the adoption of the most recent new products of the time that the study is conducted. For instance, earlier studies were conducted on cell phones (Lee, 2014), whereas recent studies conducted on wearable devices, electric vehicles (Cheung et al., 2019; Chu et al., 2019). This finding is consistent with the reality that more and more new products are introduced. The moderator role of consumer innovativeness is the second most important theme to receive the attention of scholars. It is empirically validated that $\mathrm{Cl}$ moderates various relationships such as quality and satisfaction, value and purchase intention, product characteristics, and adoption. Accordingly, it is possible to link innovativeness with other concepts in consumer behaviour literature. Antecedents of consumer innovativeness are the third-ranked and growing research theme in our sample of articles. Mostly, personal and psychological factors have been examined. The review showed that the measurement of $\mathrm{Cl}$ has been less common, indicating that it is well identified in the previous studies. According to the results of the review, three high-potential directions for future research are recommended as follows.

- The moderator role of consumer innovativeness was found as an emerging theme. Accordingly, investigating the moderating effect of $\mathrm{Cl}$ on different relationships may contribute to the literature. More studies on this theme may augment the essential role of $\mathrm{Cl}$ in consumer behaviour literature.

- The influence of consumer innovativeness on adoption intention has been a popular theme throughout the last decade. Studying the effect of $\mathrm{Cl}$ on the adoption of recent new products may still contribute to the literature. Moreover, investigating the effect of $\mathrm{Cl}$ on willingness to pay more may be beneficial. It is because the willingness to pay is accepted as a more profound commitment and closer to the actual adoption behaviour than intention (Fu and Elliott, 2013).

- To better understand the consumer innovativeness concept, different antecedents could be investigated. Psychographics are accepted as better predictors of consumer behaviour (Vyncke, 2002). Thus, more studies investigating the influence of lifestyle, personal values, and shopping motivations on consumer innovativeness are needed in determining the characteristics of innovative consumers. 
Overall, this study showed how consumer innovativeness has thrived in consumer behaviour literature. Apart from studies purely focusing on consumer innovativeness, there is a stream of research combining consumer innovativeness and other concepts via moderating and mediating effects. Accordingly, the level of innovativeness affects the roles of perceived value, quality, price, design, and so forth. The results have some practical implications at the firm level and macro level through supporting marketing strategies, economy, and sustainability. The study revealed the importance of consumer innovativeness in profiling consumers. The use of consumer innovativeness by managers in segmenting decisions may provide more valuable consumer insights. In this manner, more accurate product design and communication strategies can be developed for well-established segments of new products. Those strategies constitute an essential role in customer acceptance and thus may reduce new product failure rates. Lower rates of failure contribute to the economy; hence innovations are vital for many industries. For instance, in the median OECD country, 53\% of firms introduced new products between the years 2014-2016, and these firms accounted for $70 \%$ of business sector employment (OECD, 2019). Besides, recent studies showed the role of consumer innovativeness on the adoption of green or eco-friendly products. Accordingly, the practices devoted to sustainability issues may target innovative consumers, as well as environmentally sensitive consumers. Those innovators, in turn, may leverage the diffusion of those practices in their social system. An increasing number of studies that link consumer innovativeness and sustainable consumption may contribute to the sustainable development goals of the United Nations that supports responsible consumption and production. One of the limitations of this study is that the sample covers articles published in WOS indexed journals. Other indexes such as Scopus or EconLit may also include articles that deal with consumer innovativeness. The present review concentrated on research themes; further research may review the methodology of those studies, as well.

Funding: This research received no external funding

\section{References}

Abbas, M., \& Mir, N. Q. (2020). Exploring factors influencing consumer resistance to innovation by applying consumer resistance theory. SMART Journal of Business Management Studies, 16(1), 64-72. [Google Scholar]. [CrossRef].

Abbas, M., Zaman, U., Ahmad, J., Nawaz, M. S., \& Ahraf, M. (2019). Diffusion of mobile banking in Pakistan. SMART Journal of Business Management Studies, 15(1), 10. [Google Scholar] [CrossRef]

Adapa, S., Fazal-e-Hasan, S. M., Makam, S. B., Azeem, M. M., \& Mortimer, G. (2020). Examining the antecedents and consequences of perceived shopping value through smart retail technology. Journal of Retailing and Consumer Services, 52. [Google Scholar] [CrossRef]

Aldahdouh, T. Z., Nokelainen, P., \& Korhonen, V. (2020). Technology and Social Media Usage in Higher Education: The Influence of Individual Innovativeness. SAGE Open, 10(1). [Google Scholar] [CrossRef]

Al-Jundi, S. A., Shuhaiber, A., \& Augustine, R. (2019). Effect of consumer innovativeness on new product purchase intentions through learning process and perceived value. Cogent Business and Management, 6(1). [Google Scholar] [CrossRef]

Ashraf, R. U., Hou, F., \& Ahmad, W. (2019). Understanding Continuance Intention to Use Social Media in China: The Roles of Personality Drivers, Hedonic Value, and Utilitarian Value. International Journal of Human-Computer Interaction, 35(13), 1216-1228. [Google Scholar] [CrossRef]

Bartels, J., \& Reinders, M. J. (2010). Social identification, social representations, and consumer innovativeness in an organic food context: A cross-national comparison. Food Quality and Preference, 21(4), 347-352. [Google Scholar] [CrossRef]

Bartels, J., \& Reinders, M. J. (2011). Consumer innovativeness and its correlates : A propositional inventory for future research. Journal of Business Research, 64(6), 601-609. [Google Scholar] [CrossRef]

Biswas, A., \& Roy, M. (2015). Leveraging factors for sustained green consumption behavior based on consumption value perceptions: Testing the structural model. Journal of Cleaner Production, 95, 332-340. [Google Scholar] [CrossRef]

Byun, S. E., \& Sternquist, B. (2011). Fast fashion and in-store hoarding: The drivers, moderator, and consequences. Clothing and Textiles Research Journal, 29(3), 187-201. [Google Scholar] [CrossRef

Caricati, L., \& Raimondi, M. (2015). The motivated consumer innovativeness scale: Initial Italian validation. TPM - Testing, Psychometrics, Methodology in Applied Psychology, 22(3), 363-383. [Google Scholar] [CrossRef]

Chakrabarti, S. (2010). Factors influencing organic food purchase in India - expert survey insights. British Food Journal, 112(8), 902-915. [Google Scholar] [CrossRef

Chang, C. H., Leigh, R., Shu, S. T., \& Ma, S. C. (2019). Fitness innovativeness, duration of stay, and revisit behavior: a 
moderation relationship. International Journal of Sports Marketing and Sponsorship, 20(4), 634-645. [Google Scholar] [CrossRef]

Chao, C. W., Reid, M., \& Hung, Y. C. (2016). Vicarious innovativeness or vicarious learning: The role of existing vicarious innovativeness in new product purchase intentions. Australasian Marketing Journal, 24(1), 87-92. [Google Scholar] [CrossRef]

Chauhan, V., Yadav, R., \& Choudhary, V. (2019). Analyzing the impact of consumer innovativeness and perceived risk in internet banking adoption: A study of Indian consumers. International Journal of Bank Marketing, 37(1), 323-339. [Google Scholar [CrossRef

Chen, W. C., \& Fiore, A. M. (2017). Factors affecting Taiwanese consumers' responses toward pop-up retail. Asia Pacific Journal of Marketing and Logistics, 29(2), 370-392. [Google Scholar] [CrossRef]

Cheng, Y. H., \& Chen, S. F. (2016). Adoption forecasting of multipurpose smart cards in transit systems. Journal of Intelligent Transportation Systems: Technology, Planning, and Operations, 20(4), 363-384. [Google Scholar] [CrossRef]

Cheung, M. L., Chau, K. Y., Sum Lam, M. H., Tse, G., Ho, K. Y., Flint, S. W., ...\& Lee, K. Y. (2019). Examining consumers' adoption of wearable healthcare technology: The role of health attributes. International Journal of Environmental Research and Public Health, 16(13). [Google Scholar] [CrossRef]

Chu, W., Im, M., Song, M. R., \& Park, J. (2019). Psychological and behavioral factors affecting electric vehicle adoption and satisfaction: A comparative study of early adopters in China and Korea. Transportation Research Part D: Transport and Environment, 76, 1-18. [Google Scholar] [CrossRef]

Clark, R. A., \& Goldsmith, R. E. (2006). Interpersonal influence and consumer innovativeness. International Journal of Consumer Studies, 30(1), 34-43. [Google Scholar] [CrossRef]

Cui, F., Lin, D., \& Qu, H. (2018). The impact of perceived security and consumer innovativeness on e-loyalty in online trave shopping. Journal of Travel and Tourism Marketing, 35(6), 819-834. [Google Scholar] [CrossRef]

Davis, D. F., Golicic, S. L., \& Boerstler, C. N. (2011). Benefits and challenges of conducting multiple methods research in marketing. Journal of the Academy of Marketing Science, 39(3), 467-479. [Google Scholar] [CrossRef]

de Oliveira Santini, F., Ladeira, W. J., \& Sampaio, C. H. (2018). Tourists' perceived value and destination revisit intentions: The moderating effect of domain-specific innovativeness. International Journal of Tourism Research, 20(3), 277-285. [Google Scholar] [CrossRef]

Denyer, D., \& Tranfield, D. (2006). Using qualitative research synthesis to build an actionable knowledge base. Management Decision, 44(2), 213-227. [Google Scholar] [CrossRef]

Eren-Erdogmus, l., Akgun, l., \& Arda, E. (2018). Drivers of successful luxury fashion brand extensions: cases of complement and transfer extensions. Journal of Fashion Marketing and Management, 22(4), 476-493. [Google Scholar] [CrossRef]

Fu, F., \& Elliott, M. (2013). The moderating effect of perceived product innovativeness and product knowledge on new product adoption: An integrated model. Journal of Marketing Theory and Practice, 21(3), 257-272. [Google Scholar] [CrossRef]

Goldsmith, E. R., \& Hofacker, C. F. (1991). Measuring Consumer Innovativeness. Journal of Academy of Marketing Science, 19(3), 209-221. [Google Scholar]

Goldsmith, R. E., \& Foxall, G. R. (2003). The measurement of innovativeness. In L. V. Shavinina (Ed.), The International Handbook On Innovation (pp. 321-330). London: Pergamon. [Google Scholar]

Gumel, A. M. (2018). Does Consumer Innovativeness Matter? Predicting Customer Behaviour of A New Financial Architecture. Turkish Journal of Islamic Economics, 5(2), 145-172. [Google Scholar] [CrossRef]

Gurtner, S., \& Soyez, K. (2016). How to catch the generation Y: Identifying consumers of ecological innovations among youngsters. Technological Forecasting and Social Change, 106, 101-107. [Google Scholar] [CrossRef]

Hammersley, M. (2001). On «systematic» reviews of research literatures: a «narrative» response to Evans \& Benefield. British Educational Research Journal, 27(5), 543-554. [Google Scholar] [CrossRef]

Handarkho, Y. D., \& Harjoseputro, Y. (2019). Intention to adopt mobile payment in physical stores: Individual switching behavior perspective based on Push-Pull-Mooring (PPM) theory. Journal of Enterprise Information Management, 33(2), 285-308. [Google Scholar] [CrossRef]

Heidenreich, S., Spieth, P., \& Petschnig, M. (2017). Ready, Steady, Green: Examining the Effectiveness of External Policies to Enhance the Adoption of Eco-Friendly Innovations. Journal of Product Innovation Management, 34(3), 343-359. [Google Scholar] [CrossRef]

Hong, J. C., Lin, P. H., \& Hsieh, P. C. (2017). The effect of consumer innovativeness on perceived value and continuance intention to use smartwatch. Computers in Human Behavior, 67, 264-272. [Google Scholar] [CrossRef]

Huang, X., Soutar, G. N., \& Brown, A. (2004). Measuring new product success: An empirical investigation of Australian SMEs. Industrial Marketing Management, 33(2), 117-123. [Google Scholar] [CrossRef]

Hur, W. M., Yoo, J. J., \& Chung, T. L. (2012). The consumption values and consumer innovativeness on convergence products. Industrial Management \& Data Systems, 112(5), 688-706. [Google Scholar] [CrossRef]

Hwang, J., \& Griffiths, M. A. (2017). Share more, drive less: Millennials value perception and behavioral intent in using collaborative consumption services. Journal of Consumer Marketing, 34(2), 132-146. [Google Scholar] [CrossRef]

Hwang, J., Lee, J. S., \& Kim, H. (2019). Perceived innovativeness of drone food delivery services and its impacts on attitude and behavioral intentions: The moderating role of gender and age. International Journal of Hospitality Management, 81, 94-103. [Google Scholar] [CrossRef]

Jung, T., Chung, N., \& Leue, M. C. (2015). The determinants of recommendations to use augmented reality technologies: The case of a Korean theme park. Tourism Management, 49, 75-86. [Google Scholar] [CrossRef] 
Kaushik, A. K., \& Rahman, Z. (2014). Perspectives and dimensions of consumer innovativeness: A literature review and future agenda. Journal of International Consumer Marketing, 26(3), 239-263. [Google Scholar] [CrossRef]

Kaushik, A. K., \& Rahman, Z. (2016). Self-service innovativeness scale: introduction, development, and validation of scale. Service Business, 10(4), 799-822. [Google Scholar] [CrossRef]

Kelley, J. B., \& Alden, D. L. (2016). Online brand community: through the eyes of Self-Determination Theory. Internet Research, 26(4), 790-808. [Google Scholar] [CrossRef]

Kim, W., Benedetto, D., Anthony, C., \& Hunt, J. M. (2012). Consumer innovativeness and consideration set as antecedents of the consumer decision process for highly globalized new products: a three-country empirical study. Journal of Global Scholars of Marketing Science, 22(1), 1-23. [Google Scholar] [CrossRef

Kim, W., Di Benedetto, C., A., \& Hunt, J. M. (2017). Consumer innovativeness and international consumer behavior: Comments and extensions. Journal of Global Scholars of Marketing Science, 27(3), 184-194. [Google Scholar] [CrossRef]

Kim, W., Hunt, J. M., \& Lancioni, R. A. (2015). Consumer innovativeness: a domain-specific perspective of information acquisition and choice. Journal of Global Scholars of Marketing Science, 25(1), 17-36. [Google Scholar] [CrossRef]

Kim, Y. H., \& Kim, Y. K. (2017). A technology-fashion collaborative product: Its impact on consumer attitudes and purchase intention. Journal of Global Fashion Marketing, 8(4), 283-297. [Google Scholar] [CrossRef]

Konuk, F. A. (2018). Antecedents of pregnant women's purchase intentions and willingness to pay a premium for organic food. British Food Journal, 120(7), 1561-1573. [Google Scholar] [CrossRef]

Konuk, F. A. (2019). Consumers' willingness to buy and willingness to pay for fair trade food: The influence of consciousness for fair consumption, environmental concern, trust and innovativeness. Food Research International, 120, 141-147. [Google Scholar] [CrossRef]

Krey, N., Chuah, S. H. W., Ramayah, T., \& Rauschnabel, P. A. (2019). How functional and emotional ads drive smartwatch adoption: The moderating role of consumer innovativeness and extraversion. Internet Research, 29(3), 578-602. [Google Scholar] [CrossRef]

Kuester, S., Feurer, S., Schuhmacher, M. C., \& Reinartz, D. (2015). Comparing the incomparable? How consumers judge the price fairness of new products. International Journal of Research in Marketing, 32(3), 272-283. [Google Scholar] [CrossRef]

Lassar, W. M., Manolis, C., \& Lassar, S. S. (2005). The relationship between consumer innovativeness, personal characteristics, and online banking adoption. International Journal of Bank Marketing, 23(2), 176-199. [Google Scholar] [CrossRef]

Lee, H. C., Wang, C. Y., \& Hong, R. S. (2013). The factors influencing adolescents' purchase intentions of state-of-the-art cell phones in Taiwan. Service Business, 7(4), 713-734. [Google Scholar] [CrossRef]

Lee, K., \& Mano, H. (2014). Beyond simple innovativeness: A hierarchical continuum and thinking and feeling processing modes. Social Behavior and Personality, 42(4), 597-614. [Google Scholar] [CrossRef]

Lee, S. Y. (2014). Examining the factors that influence early adopters' smartphone adoption: The case of college students. Telematics and Informatics, 31(2), 308-318. [Google Scholar] [CrossRef]

Lee, S., \& Johnson, Z. S. (2017). The effect of new product design and innovation on South Korean consumer's willingness to buy. Asia Pacific Joumal of Marketing and Logistics, 29(1), 98-113. [Google Scholar] [CrossRef]

Lee, S., Lee, J. H., \& Garrett, T. C. (2013). A study of the attitude toward convergent products: A focus on the consumer perception of functionalities. Jourmal of Product Innovation Management, 30(1), 123-135. [Google Scholar] [CrossRef]

Lee, W. J., \& Shin, S. (2018). Effects of product smartness on satisfaction: Focused on the perceived characteristics of smartphones. Journal of Theoretical and Applied Electronic Commerce Research, 13(2), 1-14. [Google Scholar] [CrossRef]

Li, G., Zhang, R., \& Wang, C. (2015). The role of product originality, usefulness and motivated consumer innovativeness in new product adoption intentions. Journal of Product Innovation Management, 32(2), 214-223. [Google Scholar] [CrossRef]

Li, K., Rollins, J., \& Yan, E. (2018). Web of Science use in published research and review papers 1997-2017: A selective, dynamic, cross-domain, content-based analysis. Scientometrics, 115(1), 1-20. [Google Scholar] [CrossRef]

$\mathrm{Li}, \mathrm{X}$. (2013). Innovativeness, personal initiative, news affinity and news utility as predictors of the use of mobile phones as news devices. Chinese Journal of Communication, 6(3), 350-373. [Google Scholar] [CrossRef]

Lin, C., \& Nguyen, C. (2011). Exploring E-Payment Adoption in Vietnam and Taiwan. Journal of Computer Information Systems, 51(4), 41-52. [Google Scholar]

Liu, X., \& Wayne Xu, W. (2019). Adoption of ride-sharing apps by Chinese taxi drivers and its implication for the equality and wellbeing in the sharing economy. Chinese Journal of Communication, 12(1), 7-24. [Google Scholar] [CrossRef]

Lopez-Bonilla, J. M., \& Lopez-Bonilla, L. M. (2012). Sensation-Seeking Profiles and Personal Innovativeness in Information Technology. Social Science Computer Review, 30(4), 434-447. [Google Scholar] [CrossRef]

Maalouf, J. T., Abi Aad, A., \& El Masri, K. (2020). Competitiveness of sharing economy companies in emerging markets. Competitiveness Review. [Google Scholar] [CrossRef]

Mahdzan, N. S., Zainudin, R., \& Au, S. F. (2017). The adoption of Islamic banking services in Malaysia. Journal of Islamic Marketing, 8(3), 496-512. [Google Scholar] [CrossRef]

Menidjel, C., Benhabib, A., \& Bilgihan, A. (2017). Examining the moderating role of personality traits in the relationship be tween brand trust and brand loyalty. Journal of Product and Brand Management, 26(6), 631-649. [Google Scholar] [CrossRef]

Midgley, F. D., \& Dowling, G. R. (1978). Innovativeness: The Concept and Its Measurement. Journal of Consumer Research, 4. [Google Scholar] [CrossRef]

Morosan, C., \& DeFranco, A. (2016). Modeling guests' intentions to use mobile apps in hotels: The roles of personalization, 
privacy, and involvement. International Journal of Contemporary Hospitality Management, 28(9), 1968-1991. [Google Scholar] [CrossRef]

Morosan, C., \& DeFranco, A. (2019). Co-creation of value using hotel interactive technologies: examining intentions and conversion. International Journal of Contemporary Hospitality Management. [Google Scholar] [CrossRef]

Morton, C., Anable, J., \& Nelson, J. D. (2016). Exploring consumer preferences towards electric vehicles: The influence of consumer innovativeness. Research in Transportation Business and Management, 18, 18-28. [Google Scholar] [CrossRef]

Muller, P., Schmitt, J. B., \& Kramer, B. (2018). Of Rules and Role Models: How Perceptions of Parents' Mediation and Modelling Contribute to Individuals' Media Innovativeness. Journal of Broadcasting and Electronic Media, 62(4), 692-710. [Google Scholar] [CrossRef]

Murata, K., Arias-Oliva, M., \& Pelegrín-Borondo, J. (2019). Cross-cultural study about cyborg market acceptance: Japan versus Spain. European Research on Management and Business Economics, 25(3), 129-137. [Google Scholar] [CrossRef]

Nikou, S. (2019). Factors driving the adoption of smart home technology: An empirical assessment. Telematics and Informatics, 45. [Google Scholar] [CrossRef]

Norskov, S., Chrysochou, P., \& Milenkova, M. (2015). The impact of product innovation attributes on brand equity. Journal of Consumer Marketing, 32(4), 245-254. [Google Scholar] [CrossRef]

OECD (2019). Highlights from OECD Innovation Indicators 2019. Retrieved from https://www.oecd.org/sti/inno/innovationindicators-2019-highlights.pdf

Pantano, E., Priporas, C. V., \& Foroudi, P. (2019). Innovation starts at the storefront: Modelling consumer behaviour towards storefront windows enriched with innovative technologies. International Journal of Retail and Distribution Management, 47(2), 202219. [Google Scholar] [CrossRef]

Park, J., \& Gunn, F. (2016). The Impact of Image Dimensions toward Online Consumers' Perceptions of Product Aesthetics. Human Factors and Ergonomics In Manufacturing, 26(5), 595-607. [Google Scholar] [CrossRef]

Park, K., \& Lee, K. (2016). Is green product purchasing an innovative or conspicuous behavior? Social Behavior and Personality, 44(1), 29-44. [Google Scholar] [CrossRef]

Park, N. G., \& Tran, H. T. T. (2019). Making the world a better place by making better products: Eco-friendly consumer innovativeness and the adoption of eco-innovations. European Journal of Marketing, 53(8), 1546-1584. [Google Scholar] [CrossRef]

Popay, J., Roberts, H., Sowden, A., Petticrew, M., Arai, L., Rodgers, M., \& Duffy, S. (2006). Methods, Guidance on the conduct of narrative synthesis in systematic reviews. ESRC Programme, 15(1), 47-71. [Google Scholar]

Quoquab, F., Mohammad, J., Yasin, N. M., \& Abdullah, N. L. (2018). Antecedents of switching intention in the mobile telecommunications industry: A partial least square approach. Asia Pacific Journal of Marketing and Logistics, 30(4), 1087-1111. [Google Scholar] [CrossRef]

Ratten, V. (2015). International consumer attitudes toward cloud computing: A social cognitive theory and technology acceptance model perspective. Thunderbird International Business Review, 57(3), 217-228. [Google Scholar] [CrossRef]

Roehrich, G. (2004). Consumer innovativeness Concepts and measurements. Journal of business research, 57(6), 671-677. [Google Scholar] [CrossRef]

Rogers, E. M. (1983). Diffusion of innovations. New York: The Free Press.

Rohm, A. J., Gao, T. T., Sultan, F., \& Pagani, M. (2012). Brand in the hand: A cross-market investigation of consumer acceptance of mobile marketing. Business Horizons, 55(5), 485-493. [Google Scholar] [CrossRef]

San-Martin, S., \& Lopez-Catalan, B. (2013). How can a mobile vendor get satisfied customers? Industrial Management \& Data Systems, 113(2), 156-170. [Google Scholar] [CrossRef]

Schillo, R. S., Persaud, A., \& Schillo, S. R. (2017). Purchasing organic products: role of social context and consumer innovativeness. Marketing Intelligence and Planning, 35(1), 130-146. [Google Scholar] [CrossRef]

Schweitzer, F., \& Van den Hende, E. A. (2016). To Be or Not to Be in Thrall to the March of Smart Products. 33(10), 830-842. [Google Scholar] [CrossRef]

Shaikh, I. M., Qureshi, M. A., Noordin, K., Shaikh, J. M., Khan, A., \& Shahbaz, M. S. (2020). Acceptance of Islamic financial technology (FinTech) banking services by Malaysian users: an extension of technology acceptance model. Foresight. [Google Scholar] [CrossRef]

Shi, G., Bu, H., Ping, Y., Liu, M. T., Wang, Y., Tingchi Liu, M., \& Wang, Y. (2016). Customer relationship investment and relationship strength: evidence from insurance industry in China. Journal of Services Marketing, 30(2), 201-211. [Google Scholar] [CrossRef]

Simmons, G., Grinstein, A., \& Palmer, M. (2017). Branding strategies for high technology products: The effects of consumer and product innovativeness. Journal of Business Research, 70, 85. [Google Scholar] [CrossRef]

Slade, E. L., Dwivedi, Y. K., Piercy, N. C., \& Williams, M. D. (2015). Modeling Consumers' Adoption Intentions of Remote Mobile Payments in the United Kingdom: Extending UTAUT with Innovativeness, Risk, and Trust. Psychology and Marketing, 32(8), 860873. [Google Scholar] [CrossRef]

Thakur, A., \& Jasrai, L. (2018). A Logit Model to Predict Innovativeness among Mobile Telecom Service Users. Global Business Review, 19(3_suppl), S54-S71. [Google Scholar] [CrossRef]

van Oorschot, J. A., Hofman, E., \& Halman, J. I. (2018). A bibliometric review of the innovation adoption literature. Technological Forecasting and Social Change, 134, 1-21.[Google Scholar] [CrossRef]

Vyncke, P. (2002). Lifestyle segmentation: From attitudes, interests and opinions, to values aesthetic styles, life visions and 
media preferences. European Journal of Communication, 17(4), 445-463. [Google Scholar] [CrossRef]

Waheed, M., Klobas, J. E., \& Kaur, K. (2017). The importance of actual use in defining and measuring innovative behaviour: Comparison of e-book reader users and non-users. Journal of Librarianship and Information Science, 49(4), 368-379. [Google Scholar] [CrossRef]

Wang, B., Gao, Y., Su, Z., \& Li, J. (2019). The structural equation analysis of perceived product innovativeness upon brand loyalty based on the computation of reliability and validity analysis. Cluster Computing, 22, 10207-10217. [Google Scholar [CrossRef]

Wang, Q., Dacko, S., \& Gad, M. (2008). Factors Influencing Consumers' Evaluation and Adoption Intention of Really-New Products or Services: Prior Knowledge, Innovativeness and Timing of Product Evaluation. 35th Annual Conference of the Association-for-Consumer-Research, 416-422. [Google Scholar]

Wang, W. (2014). Hospitality consumers' innovativeness: A qualitative study. Advances in Hospitality and Leisure, 10, 37-56. [Google Scholar] [CrossRef]

Wang, Y., So, K. K. F., \& Sparks, B. A. (2017). Technology Readiness and Customer Satisfaction with Travel Technologies: A Cross-Country Investigation. Journal of Travel Research, 56(5), 563-577. [Google Scholar] [CrossRef]

Zhang, Z., \& Hou, Y. (2017). The effect of perceived risk on information search for innovative products and services: the moderating role of innate consumer innovativeness. Journal of Consumer Marketing, 34(3), 241-254. [Google Scholar] [CrossRef]

\section{Канан Ериіжит, Ph.D., доцент, Університет Хаджеттепе, Туреччина}

Інноваційна активність споживачів: бібліографічний аналіз

Статтю присвячено аналізуу наукового доробку у сфрері активізації інноваційної активнності споживачів. Головною метою є визначення основнх патернів наукових досліджень щодо інноваційної активності споживачів із використанням бібліометричного аналізу наукових публікацій з даної проблематики. Актуальність даної роботи полягає у заповненні прогалин попередніх вузько спеціалізвоаних та застарілих напрацювань. Детерміновану вибірку даних сформовано на основі 118 наукових статей, опублікованих за останні десять років у журналах, що індексуються базою даних Web of Science. У результаті проведеного контентаналізу досліджувані статті згруповано за п'ятьма тематиками: 1) наслідки інноваційної активнності споживачів; 2) передумови активізації інноваційної активнності споживачів; 3) управління інноваційною активнностю споживачів; 4) посередницька роль інноваційної активнності споживачів; 5) оцінювання інноваційної активнності споживачів. Результати дослідження дають підстави стверджувати, що найбільшу частку статей присвячено дослідженню переваг від підвищення інноваційної активнності споживачів. Автороммм відмічено, що випуск нового продукту $є$ найбільш поширеним результатом підвищення рівня інноваційної активнності споживачів. У свою чергу, дещо меншою є частка досліджень щодо ефрективності управління інноваційною активністю споживачів. У ході дослідження встановлено, що науковий напрям щодо оцінювання рівння інноваційної активнності споживачів $\epsilon$ менш досліджуваним. Враховуючи отримані результати, автором визначено, що дослідження посередницької ролі інноваційної активнності споживачів не були актуальними протягом останніх десяти років. При цьому автором відмічено, що інноваційна активність споживачів відіграє ключову роль у процесі прийнятття їх рішень. Крім того, тематика інноваційної активнності споживачів розглядалася у роботах, присвячених питанням поведінки споживачів.

Ключові слова: споживча інноваційність, контент-аналіз, літературний огляд, наслідки споживчої інноваційності.

Manuscript received: 25.02.2020

(C) The author(s) 2020. This article is published with open access at Sumy State University 